\title{
Atrial natriuretic peptide and blood volume during red cell transfusion in preterm infants
}

\author{
W Rascher, N Lingens, M Bald, O Linderkamp
}

\begin{abstract}
Because raised plasma concentrations of atrial natriuretic peptide indicate volume expansion, we studied the effect of red cell transfusion on plasma atrial natriuretic peptide concentration, packed cell volume, and intravascular volume in eight preterm infants. Red cell transfusion increased red cell mass, packed cell volume and erythrocyte count, but decreased plasma volume. Total blood volume, plasma atrial natriuretic peptide concentration, urine flow rate, and urinary sodium excretion did not change.

We conclude that a slow transfusion of less than $10 \mathrm{ml}$ red cells/kg body weight does not cause volume expansion with subsequent atrial natriuretic peptide release thereby affecting the cardiovascular system.
\end{abstract}

Preterm infants weighing less then $1500 \mathrm{~g}$ are often given red cell transfusions to replace blood losses and to treat refractory anaemia. ${ }^{1}$ Because haemoglobin concentration and packed cell volume correlate poorly with the red cell mass/ $\mathrm{kg}$ of body weight in preterm infants, ${ }^{23}$ it has been proposed that the red cell mass rather than the packed cell volume should be used for estimation of the red cell deficit. ${ }^{4}$

The volume expansion resulting from red cell transfusion increases the risk of intraventricular haemorrhage in preterm infants. ${ }^{56}$ Atrial natriuretic peptide is released when volume expands in children ${ }^{7}$ as well as in fetuses. ${ }^{8}$ Raised plasma concentrations of atrial natriuretic peptide have been found in preterm infants with respiratory distress syndrome, ${ }^{9}$ increased sodium intake, ${ }^{10}$ and with patent ductus arteriosus. ${ }^{1112}$ Moreover, atrial natriuretic peptide concentrations seemed to correlate with volume changes in preterm and full term neonates. ${ }^{1314}$ This indicates that atrial natriuretic peptide may be a sensitive indicator of volume changes. There have been to our knowledge no studies on the effect of transfusion on plasma atrial natriuretic peptide in preterm infants. We have therefore studied the packed cell volume, intravascular volume, and plasma concentration of atrial natriuretic peptide in preterm infants before and after transfusion of red blood cells.

\section{Patients and methods}

Eight preterm infants with a median gestational age of 28 weeks (range 25-34) and birth weight of $1025 \mathrm{~g}$ (range 650-1800) received red cell transfusions for anaemia at a median of $\mathbf{4 1}$ days of age (range 1 to 96). Their median weight was
$1710 \mathrm{~g}$ (range 650-2660). All infants were in good clinical condition. Four were mechanically ventilated through an intratracheal tube. None had renal disease, shock, sepsis or were being treated with diuretics. The volume of transfused red cells was calculated to raise the packed cell volume to 0.45 (haemoglobin to $155 \mathrm{~g} / \mathrm{l}$ ). The transfusion rate averaged $0.05 \quad(0.01)$ $\mathrm{ml} / \mathrm{min} / \mathrm{kg}$.

Before and one hour after red cell transfusion blood was drawn in EDTA coated tubes (1.5-2 $\mathrm{ml}$ ) for determination of plasma atrial natriuretic peptide and haemoglobin concentrations packed cell volume, haemoglobin $F$ concentration, and plasma osmolality. In addition $0.5 \mathrm{ml}$ blood was drawn in plastic tubes for measurement of serum sodium, potassium and creatinine concentrations. The packed cell volumes of all red cell concentrates were also measured.

Timed urine specimens were collected before, during, and after red cell transfusion for measurement of the urinary flow rate, creatinine, osmolality, and sodium and potassium concentrations.

The circulatory red cell mass of the infants was estimated from the dilution of haemoglobin $F$ by the transfused red cells (that is, by haemoglobin A) as described by Phillips et al. ${ }^{4}$ Haemoglobin F was estimated by a modified alkali denaturation procedure. ${ }^{15}$ Red cell mass (RCM) before transfusion was calculated from the transfused red cell volume $(V)$, and the haemoglobin $\mathrm{F}$ percentages before $(\mathrm{HbF} \mathrm{l})$ and after (HbF 2) the transfusion. ${ }^{4}$

$$
R C M=\frac{V \times H b F 2}{\text { HbF 1-HbF 2 }}
$$

Red cell mass after transfusion was calculated as the sum of the pretransfusion red cell mass and transfused red cell volume. Total blood volume was calculated from the red cell mass divided by the packed cell volume. Plasma volume was derived by subtraction of the red cell mass from the total blood volume. In adults whole blood packed cell volume is usually calculated by multiplication of the venous packed cell volume by 0.9 ; as in preterm infants the whole body:venous packed cell volume ratio may vary widely we have not corrected the venous packed cell volume. ${ }^{16}$ Plasma atrial natriuretic peptide was measured by radioimmunoassay after extraction as previously described. ${ }^{7}$

Statistical analysis was done by the Wilcoxon rank sum test for paired observations and correlations were calculated by the method of least squares. Values are given as mean (SEM). The study was approved by the ethics committee of the University Children's Hospital and 
Table 1 Laboratory findings before and after red cell transfusion in eight preterm infants. Figures are expressed as mean (SEM)

\begin{tabular}{|c|c|c|c|}
\hline & $\begin{array}{l}\text { Before red cell } \\
\text { transfusion }\end{array}$ & $\begin{array}{l}\text { After red cell } \\
\text { transfusion }\end{array}$ & $\stackrel{p}{\text { Value }}$ \\
\hline $\begin{array}{l}\text { Body weight }(\mathrm{g}) \\
\text { Packed cell volume } \\
\text { Haemoglobin }(\mathrm{g} / \mathrm{l}) \\
\text { Erythrocyte count }\left(\times 10^{12} / \mathrm{l}\right) \\
\text { Red cell mass }(\mathrm{ml} / \mathrm{kg} \text { body weight }) \\
\text { Total blood volume (ml/kg body weight) } \\
\text { Plasma volume }(\mathrm{ml} / \mathrm{kg} \text { body weight) } \\
\text { Serum sodium }(\mathrm{mmol} / \mathrm{l}) \\
\text { Serum chloride }(\mathrm{mmo} / \mathrm{l}) \\
\text { Serum potassium }(\mathrm{mmol} / \mathrm{l}) \\
\text { Plasma osmolality (mmol } / \mathrm{kg}) \\
\text { Plasma atrial natriuretic peptide (pmol/l) }\end{array}$ & $\begin{array}{l}1070(200) \\
0 \cdot 35(0 \cdot 21) \\
120(7) \\
3 \cdot 4(0 \cdot 2) \\
32 \cdot 3(6 \cdot 4) \\
91 \cdot 9(14 \cdot 2) \\
59 \cdot 0(8 \cdot 2) \\
140 \cdot 2(0 \cdot 8) \\
102 \cdot 6(2 \cdot 4) \\
5 \cdot 1(0 \cdot 2) \\
284 \cdot 0(11 \cdot 9) \\
50 \cdot 1(16 \cdot 2)\end{array}$ & $\begin{array}{l}1060(200) \\
0 \cdot 43(0 \cdot 26) \\
136(8) \\
4 \cdot 5(0 \cdot 2) \\
39 \cdot 0(6 \cdot 2) \\
90 \cdot 8(11 \cdot 5) \\
51 \cdot 8(5 \cdot 8) \\
140.5(1.9) \\
104.0(2 \cdot 4) \\
4.9(0 \cdot 4) \\
283.7(7 \cdot 0) \\
48.0(17 \cdot 8)\end{array}$ & $\begin{array}{l}<0.02 \\
<0.02 \\
<0.02 \\
<0.02 \\
<0.78 \\
<0.02 \\
<0.49 \\
<0.25 \\
<0.29 \\
<0.68 \\
<0.72\end{array}$ \\
\hline
\end{tabular}

Table 2 Clearances, urine flow rate, and absolute and fractional excretion of sodium and potassium before, during, and after red cell transfusion in preterm infants. Figures are expressed as mean (SEM)

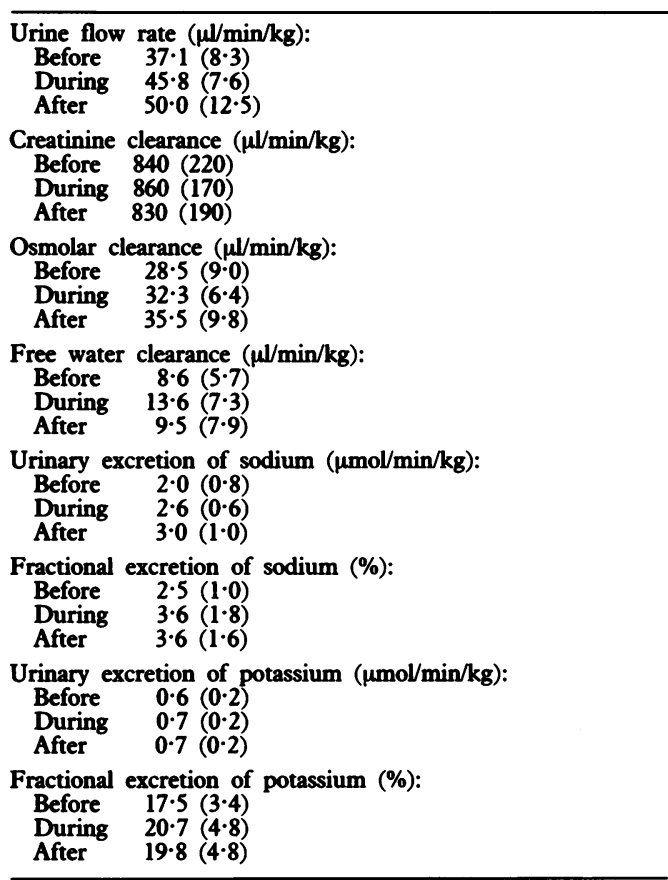

None of the differences are significant.

informed consent was obtained from the parents in each case.

\section{Results}

Red cell transfusion resulted in a significant increase in red cell mass, packed cell volume, haemoglobin, and erythrocyte count $(p<0.02$ in each case, table 1). Plasma volume fell $(p<0 \cdot 02)$. Total blood volume, plasma concentration of atrial natriuretic peptide, serum concentrations of sodium and potassium, and plasma osmolality did not change (table 1). Transfusion did not significantly alter urine flow rate, creatinine clearance, osmolar and free water clearances, and absolute and fractional excretions of sodium and potassium (table 2). There was no significant correlation between red cell mass and packed cell volume, haemoglobin, or red cell count.

\section{Discussion}

The results indicate that slow transfusion of red cells $(0.05(0.01) \mathrm{ml} / \mathrm{min} / \mathrm{kg})$ increases the amount of circulating erythrocytes in preterm infants without significantly affecting the cardiovascular system by acute volume load and subsequent atrial natriuretic peptide release. As the average intravascular volume did not rise, the average plasma atrial natriuretic peptide concentration also remained unchanged (table 1). Consequently, urine flow rate, creatinine clearance, and sodium excretion did not change significantly, although five of eight infants showed slight increases in urinary flow rate, urinary sodium excretion, and fractional sodium excretion. These measurements fell in the three other infants, however, indicating that in this small group of patients there was no consistent response of natriuresis and diuresis after red cell transfusions.

The exact mechanism of atrial natriuretic peptide secretion is not fully understood. Distension of the left and the right atrium is associated with atrial natriuretic peptide release. ${ }^{17} 18$ It is not known what degree of volume expansion is necessary for atrial distension gross enough to result in subsequent atrial natriuretic peptide release. In studies on the association of acute volume expansion and rise in plasma atrial natriuretic peptide, blood volume was expanded by $30 \% .{ }^{17}{ }^{19}$ We have recently shown that rapid volume loading with whole blood during exchange transfusion in newborns is associated with an increase in plasma atrial natriuretic peptide concentration. ${ }^{20}$ Our present study suggests that if the volume expansion is slow enough or small enough it does not cause the atrial stretch that results in subsequent atrial natriuretic peptide release.

Pretransfusion red cell mass was not significantly related to packed cell volume, haemoglobin concentration, or erythrocyte count. This confirms the results of Phillips $e t a l,{ }^{4}$ who found a weak correlation between red cell mass and packed cell volume in 33 preterm infants $(r=$ $0 \cdot 32$ ). This can be explained by a variation of total blood volume in preterm infants.

Although we calculated transfusion volume to raise the haemoglobin concentrations to $155 \mathrm{~g} / 1$ we reached only a mean haemoglobin concentration of $136 \mathrm{~g} / \mathrm{l}$. In our experience this is common in clinical practice. Perhaps the formula on which such calculations are based ( $3 \mathrm{ml}$ of packed red blood cells $\times \mathrm{kg}$ body weight $\times$ haemoglobin deficit in $\mathrm{g} / 100 \mathrm{ml}$ ) should be revised. ${ }^{21}$

We conclude that a slow transfusion of less than $10 \mathrm{ml}$ of red cells/kg body weight does not 
affect the cardiovascular system by volume expansion leading to subsequent release of atrial natriuretic peptide.

This study was supported by a grant from the Deutsche This study was supported by a grant
Forschungsgemeinschaft $(\operatorname{Ra} 326 / 1-4)$.

1 Stockman J. Anemia of prematurity, current concepts in the issue of when to transfuse. Pediatr Clin North Am 1986;33 111-28.

2 Blanchette V, Zipursky A. Assessment of anemia in newborn infants. Clin Perinatol 1984;11:489-510.

3 Faxelius G, Raye J, Gutberlet R, et al. Red cell volume measurements and acute blood loss in high-risk newborm measurements and acute blood loss

4 Phillips HA, Abdel-Muis A, Jones JG, et al. Determination of red-cell mass in assessment and management of anaemia in red-cell mass in assessment and management of anaemia in

5 Dykes F, Lazzara A, Ahmann P, Blumenstein B, Schwartz J, Brann A. Intraventricular hemorrhage: a prospective Brann A. Intraventricular hemorrhage: a prospective

6 Goldberg R, Chung D, Goldman S, Bancalari E. The association of rapid volume expansion and intraventricula hemorrhage in the preterm infant. $\mathcal{F}$ Pediatr 1980;96: 1060-3.

7 Rascher W, Tulassay T, Lang R. Atrial natriuretic peptide in plasma of volume-overloaded children with chronic rena failure. Lancet 1985;ii:303-5.

8 Robillard JE, Weiner C. Atrial natriuretic factor in the human fetus: effect of volume expansion. $\mathcal{J}$ Pediatr 1988 113:552-5.

9 Shaffer SG, Geer PG, Goetz KL. Elevated atrial natriuretic factor in neonates with respiratory distress syndrome. f Pediatr 1986;109:1028-33.
10 Tulassay T, Rascher W, Seyberth $H$, Lang R, Toth $M$, Sulyok $E$. Role of atrial natriuretic peptide in sodium homeostasis in premature infants. $f$ Pediatr 1986;109: 1013-27.

11 Rascher $\mathbb{W}$, Seyberth HW. Atrial natriuretic peptide and patent ductus arteriosus in preterm infants. Arch $D$ is $C$ hild patent ductus arter

12 Andersson S, Tikkanen I, Pesonen E, Meretoja O, Hynynen $M$, Fyhrquist $F$. Atrial natriuretic peptide in patent ductus arteriosus. Pediatr Res 1987;21:396-8.

13 Tulassay T, Seri I, Rascher W. Atrial natriuretic peptide and extracellular volume contraction after birth. Acta Paediat Scand 1987;76:444-6.

14 Kojima T, Fukada Y, Hirata Y, et al. Relationship between plasma atrial natriuretic peptide concentrations and cardiothoracic ratio during the early neonatal period. Acto Paediatr Scand 1989;78:29-33.

15 Wimberley P. Fetal hemoglobin, 2-3-diphosphoglycerate and oxygen transport in the newborn premature infant. Scand oxy Clin Lab Invest 1982;92:39-41.

16 Linderkamp $O$. Placental transfusion: determinations and effects. Clin Perinatol 1982;9:559-92.

17 Lang R, Thölken H, Ganten D, Luft F, Ruskoaho H, Unger Th. Atrial natriuretic factor-a circulating hormone Th. Atrial natriuretic factor-a circulating hormone

18 Lang RE, Dietz R, Merkel A, Unger Th, Ruskoaho H, Ganten D. Plasma atrial natriuretic peptide values in cardic disease. F Hypertens 1986;4(suppl 2):119-23.

19 Tulassay T, Rascher W, Lang R, Seyberth H, Schärer K. Atrial natriuretic peptide and other vasoactive hormones in nephrotic syndrome. Kidney Int 1987;31:1391-5.

20 Khoor A, Tulassay $T$, Bald M, Rascher W. Changes in plasma concentrations of atrial natriuretic peptide during exchange transfusion in premature infants. Acta Paediat Scand 1990;79:513-7.

21 Glader BE. Erythrocyte disorders in infancy. In: Avery ME, Taeusch HW, eds. Schaffer's diseases of the newbom. Philadelphia: Saunders, 1984:581-615. 